\title{
Role of In-service teacher training as a tool for the student's performance in selected public secondary schools in Kisoro District
}

\begin{abstract}
Received 12 October, 2021 Revised 5 December, 2021

Accepted 9 December, 2021

Published 3 January, 2022

\section{Ponsiano Mugarura1, Fredrick Ssempala ${ }^{2 *}$, and Sarah Nachuha ${ }^{3}$}

${ }^{1}$ Kabale University,Uganda

${ }^{2}$ Senior Lecturer, Faculty of

Education, Kabale University, Uganda,

${ }^{3}$ Senior Lectuerer, Faculty of Science,

Kabale University, Uganda.

*Corresponding Author Emails:

fssempal@syr.edu,

fssempala@kab.ac.ug

fssempala2@gmail.com

Tel.+256772514425/256753113767

In-service training is very important in the life of a learner and general performance of the school. Student achievement is linked to numerous factors, but quality teachers are one of the most important components of student success. If school teachers do not have the tools they need to teach students effectively, their students will not get quality education. The major purpose of the study was to assess the role of teacher In-service training as a tool for the student's performance in selected public schools in Kisoro district. The study applied a mixed methods research design which involved both quantitative and qualitative methods to collect and analyze data. Quantitative data were collected using questionnaire while qualitative data, in-depth interviews. Study sample included the district inspector of schools and District Education Officer and 238 teachers in Kisoro district. It also positively contributes to teacher's performance. Importantly also, in-service teacher training according to the findings motivates teachers for better results. To teach effectively, teachers need access to ongoing teacher professional development. This professional development enables teachers to improve their own education through seminars, workshops, and classes among others. The study therefore recommends that teachers should frequently be afforded study leaves or time off to do training. During this period, the school can hire part-time teachers so that normal learning is not disrupted. It's important to appreciate that continual professional development gives teacher's time to learn and implement new strategies.
\end{abstract}

Keywords: In-service teacher training, student's performance, professional development, achievement

\section{INTRODUCTION}

In-service training is very important in the life of a learner and general performance of the school (Okiror and Winterbottom, 2017). Student achievement is linked to numerous factors, but quality teachers are one of the most important components of student. It also assumes that circumstances change and hence the need to cope with the changes. In-service teacher training allows for such activities that may include seminars, workshops, conferences, classes and exhibitions among others that are designed to develop and improve employees in an organization from the initial employment stage to retirement. The study informed stakeholders particularly from Kisoro district on the importance of training and developing their teachers and put more emphasis on in-service teacher training program and this provided opportunities for teacher education institutions to provide service in an essential area of national development

In-service teacher training is globally practiced with the belief that it fosters professional development of teachers (Osamwonyi, 2016). Specifically, the training has been adopted to promote continuous improvement of teaching staff, eliminate differences within the background preparation of teachers, keep the teaching profession abreast of new knowledge, enable realization of creative innovations, and facilitate teachers to tackle responsibilities associated with the changing learning environment (Osamwonyi, 2016).

\section{Theoretical Perspective}

This study is based on the training theory developed by Kirkpatrick in 1959 which looks at learning and training evaluation aspects in three critical areas which are; reaction, behavior and results. Reaction explains the response of the persons participating in the training experience. It explains the relevance the participants attach to a training session. On learning, the Kirkpatrick's (1996) theory looks at the increase in knowledge or intellectual capability before and after training. It looks at the new aspects that have been learned and at the relationship between what the learners have learned and what was intended to be the outcome, the end relationship between criterion behavior 
and terminal behavior. The behavior aspect explains the extent to which trainees applied the learning got to change their behavior, this could be immediate or several months after the training. Then it also analyses whether the change in behavior was sustainable. On the results, this explains the effect on business environment or performance resulting from the training. Measures would be organizational key performance indicators such as output volumes, timescales, staff turnover, attrition, wastages, growth retention, achievement of standards and accreditations (Kirkpatrick's, 1959).

This theory is relevant to the study in that a teacher will have improved reaction in his or her place of work as a result of training an act that will make his or her performance to improve. If a teacher realizes that the training he or she undertook or is undertaking has a positive outcome, and then such a teacher will invest a lot in the training otherwise the teacher may want to have nothing to do with the training if a negative relationship is predicted.

\section{Contextual Perspective}

In-service teacher training refers to the relevant courses and activities in which a serving teacher participates to upgrade his/her professional knowledge, skills, and competence in the teaching profession. This encompasses all forms of education and training given to a teacher who is already on the job of teaching and learning. In-Service teacher training allows for such activities that may include seminars, workshops, conferences, classes and exhibitions among others that are designed to develop and improve employees in an organization from the initial employment stage to retirement.

As Duyga and Muhterem (2012), rightly pointed out the skill appropriate for generation ago might no longer prepare students for the world beyond school. Students are being tasked to be more creative and thoughtful in their daily activities. It should be noted that training of teachers on the job (in-service training) is very important in the life of a learner and general performance of the school. Student achievement is linked to numerous factors, but quality teachers are one of the most important components of student success (Duyga and Muhterem, 2012). If school teachers do not have the tools they need to teach students effectively, their students will suffer. To teach effectively, teachers need access to ongoing teacher professional development. This professional development enables teachers to improve their own education through seminars, workshops, and classes among others.

As in any other profession, it is vital that teachers keep up to date on the most current concepts, thinking and research in their field. This, in turn supports in their 'lifelong learning' as educators, as professionals and as individuals who are responsible for the education of the next generation (Wetungu, 2012). This work is intended to examine the role of in service teacher training in improving the teaching and learning process in selected public secondary schools in Kisoro district.

\section{Statement of the problem}

In Uganda teachers training program in public secondary schools is not well planned, not systematically implemented and not coordinated in some districts including Kisoro District. "Per district teachers, little or no attention is paid to professional development of teachers. This could be evidenced by the lack of management, planning and initiative for training and development programs for teachers. Consequently, the teachers self-arrange for their further education (Wetungu, 2012). Due to lack of resources, many teachers are unable to pursue higher education and thereby, lack competence. All these factors contribute to low performance and poor retention of staff in the public schools in Uganda." This may lead to the lack of competence, and hence low staff performance. There can be also a problem of low staff retention in the office. This study therefore was intended to assess the role of in-service teacher training as a tool for the student's performance in selected Secondary Schools in Kisoro district.

\section{Research Questions}

The study was guided by the following questions

(i)What is the role of in-service training among teachers in Kisoro District?

(ii)To what extent has in-service training contributed on teacher performance of teachers in Kisoro district?

(iii)What are teachers' views (reaction) on in-service teacher training in Kisoro district?

\section{Significance of the Study}

The study informed stakeholders particularly from Kisoro district on the importance of training and developing their teachers and put more emphasis on in-service teacher training program and this provided opportunities for teacher education institutions to provide service in an essential area of national development (Adile and Muhterem, 2012)

The study was useful to students and academicians as it formed a body of knowledge in getting scholars literature review that was used to identify research gaps which worked as a basis for further research in future investigation.

Teachers need to always attend in-service training programmes such as workshops, seminars, exhibitions and classes. Importantly, such programmes help in improving the teaching methods, teacher-pupil relationships and ultimately school performance (Merfat, 2016).

\section{Literature Review}

\section{Role of in-service training among teachers}

Morgan (2010), in his study on benefits of professional development, found out that teachers acquire more knowledge which can help them deliver more while in the class (Hill and Ball, 2015), indicated that teachers with little training have too little knowledge of the subjects they teach thus denying their students the most basic learning resources. According to Hill and Ball (2015), the best way to increase teachers' effectiveness in the classroom is through regular and high quality teacher training. Teachers themselves report that, the more time they spend in training activities, the more likely they were to indicate that it had improved their instructional skills. Effective teachers have good strategies for helping students. Training works as a catalyst which provokes a significant change in a teacher. Redefines role, broadens vision and enhances the attributes of a teacher. The inservice teacher training enables the teachers to be more systematic and logical in their teaching style (Kazmi and Mumtaz, 2011). Though similar studies are to be conducted in Uganda in the current research to establish if similar results were obtained in order to fill in the gap that was left out by the authors in their studies.

Time and duration of any in-service training is relevant for teachers. Courses which are conducted during school period or those conducted in the evening are not favored by teachers 
(Ahmadi and Keshavarzi, 2012). The third indicator is administration of the training, comprising methods of teaching, facilities and skills of course instructor. According to Cimer et al (2010), the combination of different methods such as presentation, modeling, practice, feedback and coaching enhance in-service training among teachers. Therefore, this research filled in that research gap that was left out by the author.

In the process of teaching in all types of schools teacher is key elements, teachers' education should be available for all school teachers regardless of their school type. In the entire spectrum of educational activities teacher occupies most crucial position, and the role of teacher is vital for bringing of effective changes (Akhter et al., 2011). Khan (2016) conducted a study to examine the impact of training through second science education project (SEP II). The study was aimed to evaluate the importance of in-service teacher training programme of second science education project for science teachers and found that this training resulted in an improvement in the content knowledge, delivery skills, lab management skills and professional attitude of in-service science teachers. Ferguson and Ladd (2011), conducted a similar research to study the performance of trained primary school teachers with and without in-service training in Hazara Division. The main focus of the study was to evaluate the role of in-service training programmes. For this purpose researcher collected data through observation of the performance of both, trained and untrained teachers and found that primary teachers, trained through different in-service teacher training programmes, were better in performance, than the untrained teachers. Though similar studies are to be conducted in Uganda in the current research to establish if similar results were obtained, therefore this research filled in the gap that was left out by the author.

On the contrary to the mentioned studies which show the positive effects of in-service training in the achievement of required skills Kazmi and Mumtaz (2011), reviewing some studies, says "studies performed on teachers' in-service training show some evidence of their weaknesses. Generally these programs have been planned by people, who are not teachers, and it can be said that these people do not take into account teachers' emotions and their requirements; therefore, they are taught by methods that do not create motivation in them to apply them."Though similar studies are to be conducted in Uganda in the current research to establish if similar results will be obtained, therefore, this research filled in the gap that was left out by the author.

Khan (2016) conducted a study to evaluate the effectiveness of PEP-ILE training programme in Tehsil Sawabi in Khyber Pakhtunkhwa province Pakistan. The main focus of the study was to evaluate the implementation of programme with special reference to training content, methodology, supervision and assessment. Data was collected through questionnaire from teachers of diverse qualification and it was concluded that the methods introduced by the PEP-ILE training programme in tehsil Sawabi have proved valuable as a monitoring tool. Another study conducted in this regard was by Ferguson and Ladd (2011), who evaluated the role of in-service teacher training programmes arranged by teacher training project in Punjab. Researcher found that although there was no significant difference in the attitude of trained and untrained teachers, yet the achievement level of the students was high who were taught by trained teachers. However, there are so many inconsistencies in their research since they did not give the number of teachers affected and hence this research filled in the gap that was left out by the author which as intended to be filled by this study.

A study by Hill and Ball (2015) explored the effects of teachers' mathematical knowledge for training on teachers. The study explored whether and how teachers 'mathematical knowledge for teaching contributes to gains in students' mathematics achievement. A linear mixed model methodology was used, from which it was discovered that teachers' mathematical knowledge was significantly related to student achievement gains in both first and third grades controlling for key students and teachers level covariates. While this result was consistent with findings from the educational production function literature the results were obtained using a measure of the specialized mathematical knowledge and skills used in teaching mathematics (Hill, Rowan and Ball, 2015). However, the current study was intended to use a smaller population compared to the one used before to observe if the results is to give similar results and hence filling in research gap.

\section{How in-service training has contributed of on teachers performance}

Morgan (2010), in his study on benefits of professional development, found out that teachers acquire more knowledge which can help them deliver more while in the class. Hill and Ball (2015), indicated that teachers with little training have too little knowledge of the subjects they teach thus denying their students the most basic learning resources and this affects their teaching and learning. Teachers' level of education have a dramatic impact on their' positive development (Castillo and Brackett, 2013). Field experts indicated that the success would be low if teachers were not placed at the center in educational policies. Teachers' continuance of their professional development through in-service teacher training is one of the main characteristics of executing successful education at schools. Attracting attention to this issue, Castillo and Brackett, (2013), draw attention to in-service teacher training programs that are prepared for teachers in order to fill the gap between developments in education and preparing teachers for instruction. The ultimate aim of in-service teacher training programs are to ensure the performance of teachers in the classroom and to increase student achievement consequently and this has not been the case in most schools in Uganda hence the study.

When teachers participate in training, it can improve teacher quality and ultimately enhance their performance. A national study of over 1,000 mathematics and science teachers found similar results in Japan. Therefore sustained and intensive training is more likely to have an influence on enhanced teacher knowledge and skills and consequently student achievement than short training activities (Guskey and Clifford (2013) noted that the ultimate goal of teacher training is improving student outcomes. It is also worth noting that teachers who are well prepared and trained are more effective teachers in the classroom and therefore have the greatest influence on the student achievement. Though similar studies are to be conducted in Uganda in the current research to establish if similar results were obtained in order to fill in the gap that was left out by their study.

Teachers get involved in training which lets them try out new instructional approaches and get immediate feedback that enhances their performance. In the District of Columbia teachers are granted five in-service days during the school year which takes place in August. When teachers participate in training, it can improve teacher quality and ultimately enhance their performance. A national study of over 1,000 mathematics and science teachers found similar results. Therefore, sustained and intensive training is more likely to have an influence on enhanced teacher knowledge and skills and consequently improving their 
performance. Guskey and Clifford (2013) noted that the ultimate goal of teacher training is improving student outcomes

Teachers themselves report that, the more time they spend in training activities, the more likely they were to indicate that it had improved their instructional skills. Effective teachers have good strategies for helping students. Training works as a catalyst which provokes a significant change in a teacher. Redefines role, broadens vision and enhances the attributes of a teacher. The inservice teacher training enables the teachers to be more systematic and logical in their teaching style (Kazmi and Mumtaz, 2011).

\section{Teachers' views on in-service teacher training programs}

Work and is integrated into the daily life of the school and has a positive influence on student achievement. In a separate study in the Virginia state, USA, Wenglinsky (2010) assessed the effects of teacher professional development on the use of new technologies in teaching. He found out a greater influence of teacher training on the use of technological equipment like computers and projectors. However, on the influence of teacher leadership on student academic achievement in Columbia, recommended that there was need for more staff training programs to enhance effective use of resources. There is no doubt that in-service education will continue to fill the missing links created by the changing society between pre-service education and teacher's role in the world of work. In-service training will be developed as an integral part of continuing teacher education. No matter the efficiency of the preservice training we give to teachers, there will necessarily be areas of inadequacies. In-service education of teachers will continue to fill these gaps e.g. for library services education, evaluation techniques. Guidance and counseling etc, and will systematically planned so that successful attendance at a number of such courses will attract incremental credits and/or count towards future advancement.

In-service training will be developed as an integral part of continuing teacher education. No matter the efficiency of the preservice training we give to teachers, there will necessarily be areas of inadequacies. In-service education of teachers will continue to fill these gaps e.g. for library services education, evaluation techniques (Castillo and Brackett, 2013). Guidance and counseling etc, and will systematically planned so that successful attendance at a number of such courses will attract incremental credits and/or count towards future advancement. However this may not be effective in my opinion since most teachers are not trained and this may hinder quality of teaching. Therefore, the development of the human resources assumes that the process is continuous and there is always room for improvement. It also assumes that circumstances change and hence the need to cope with the changes. In-service teacher training allows for such activities that may include seminars, workshops, conferences, classes and exhibitions among others that are designed to develop and improve employees in an organization from the initial employment stage to retirement (Osamwonyi, 2016).

\section{MATERIALS AND METHODS}

\section{Study Design and Data Collection}

\section{Study Area}

This study was conducted in selected secondary schools. Kisoro district has a total of 33 Secondary Schools. Three secondary schools will be considered out of 33 schools. The schools were selected due to the fact that they trained teachers who underwent in-service teacher training. Therefore, the researcher wanted to assess the effect of in-service teacher training on teachers' work performance. The choice of those secondary schools was attributed to the regular high performance in Uganda Certificate examinations thus seeking to know as to whether there was any relationship between in-service teacher training and students' performance.

\section{Study Population and sample}

The study population included teachers of three selected secondary. The entire population of 238 teachers, District Education Officer and inspector of schools constituted the sample i.e. a total of 240 respondents made up the sample size.

\section{Sampling Techniques}

Purposive sampling was used to select the school basing on the performance. Considering that the population size for the teachers is manageable, the study adopted the census method where all the teachers in the school were included in the sample. The sample was then stratified into females and males. Purposive sampling was used to select key informants i.e. the district inspector of schools and DEO.

\section{Methods of Data Collection and Analysis}

\section{Methods of data collection}

The study employed both primary and secondary data collection methods. The study employed a quantitative method in form of surveys to generate responses towards the various issues of concern. The survey method enabled the researcher to directly reach out to respondents in the field and inquire much about the subject under study. The interviews enabled the researcher collect qualitative data as well.

\section{Data Collection tools}

Data was collected using a closed ended Self-Administered Questionnaire (SAQ). Section A, was designed to generate the demographic characteristics of respondents. Section B of the questionnaire was formulated based on specific objectives. The question based on a five Likert scale (Strongly agree, Agree, Neutral, Disagree, Strongly disagree). It is hoped that the questionnaires helped to capture socio-demographic characteristics of the respondents and their knowledge on the role of in-service teacher training as a tool for the student's performance in selected public secondary Schools in Kisoro District:

Document Review is in away a form of qualitative research where documents are examined by the researcher to give meaning centered on a topic of assessment. Different documents were used to obtain information to back up the research results.

Oral interview is the interaction of researcher and respondent of face to face (Robson, 2002).The researcher conducted face to face interview with key informants: the district inspector of schools and DEO. An interview guide was used to guide the interview process. This method provided an interactive platform that enabled the researcher to collect first-hand information over what these key informant respondent think, know or feel about the role of in-service teacher training as a tool for the student's 
Table 1. In-service teaching training improves on the standard of teaching

\begin{tabular}{lcccc}
\hline & Frequency & Percent & Valid Percent & Cumulative Percent \\
\hline Neutral & 38 & 16.0 & 16.0 & 16.0 \\
Agree & 130 & 54.6 & 54.6 & 70.6 \\
Strongly agree & 70 & 29.4 & 29.4 & 100.0 \\
\hline Total & 238 & 100.0 & 100.0 & \\
\hline
\end{tabular}

Source: Field data 2021

Table 2.In-service teacher training ensure the effectiveness of teachers in classroom and increase achievement

\begin{tabular}{lccc}
\hline Frequency & Percent & Valid Percent & Cumulative Percent \\
\hline Disagree & 2 & 8 & 8 \\
Neutral & 30 & 12.6 & 12.6 \\
Agree & 113 & 47.5 & 47.5 \\
Strongly agree & 93 & 39.1 & 39.1 \\
\hline Total & $\mathbf{2 3 8}$ & $\mathbf{1 0 0 . 0}$ & $\mathbf{1 0 0 . 0}$ \\
\hline
\end{tabular}

Source: Field data 2021

performance in selected public secondary Schools in Kisoro District:

\section{Methods of data Analysis}

Descriptive and inferential statistics were used to analyze the quantitative data collected on SAQs. Data was coded, edited, categorized and entered into Statistical Package for Social Science (SPSS) version 22 for generation of summary frequency tables.

\section{Ethical Consideration}

Ethical issues arise when there is no reciprocity between the researcher and participants. Participants may also want or not want to have their identities remain confidential .This study therefore took into consideration of ethical issues that accrue to it.

Permission to conduct research was sought from Kabale University, after which the researcher was able to go to the field to gather the required information for the final research report.

Furthermore informed consent was sought at school level from the eligible study participants were assured of confidentiality of any information provided. This was assured by using codes for the information attained from the participants. Finally, the participants were informed of any benefits whatsoever that the study would entail.

\section{FINDINGS/ RESULTS}

According to the Table 1, 16.0\% of the respondents were neutral on the statement that in service training improves on the standards of teaching, 54.6\% agreed and 29.4\% strongly agreed. Since the majority agreed, it's true that in-service teacher training positively impacts on the learning objectives/standards.

According to the Table 2 respondents stated that in-service teacher training ensure the effectiveness of teachers in classroom and increase achievement, $8 \%$ were disagreed, $12.6 \%$ were neutral, $47.5 \%$ agreed, while $39.1 \%$ strongly agreed. As such, we can assert that in-service teacher training ensure the effectiveness of teachers in classroom and increase achievement.
From the Table 3, 3.8\% of the respondents disagreed that inservice teacher training advances training in class for better, $17.6 \%$ were neutral, the majority $48.7 \%$ agreed while $29.8 \%$ strongly agreed. This implies that in-service teacher training advances training in class for better. According to a key interviewee, "when a teacher is trained, we expect the quality of assignments he gives to students to also be of high quality" he said.

The findings in Table 4 above show that In-service teacher training advances training in class for better results which leads to creativity and training $(r=232$ at $\mathrm{p}=.000<0.01)$ hence rejecting the null hypothesis. This implies that in-service teacher training advances training in class for better results

According to the Table 5, 6.7\% of the respondents disagreed, $29.4 \%$ ere neutral, $44.5 \%$ who were the majority agreed $19.3 \%$ strongly agreed \%. The implication is that inservice training leads to creativity and training. Some key informants argued that when a teacher is re-trained, it improves his/her ability to use modern resources such as videos in the classroom and making good presentations for his students. This has an overall influence on the curriculum. Although such can be achieved after the initial training, we hasten to add that improvements can be realized after further training.

According to the Table 6, $8 \%$ of the respondents strongly disagreed that in-service training increases confidence among student $8 \%$ disagreed, $26.1 \%$ were neutral on the issue $52.5 \%$ agreed and $47 \%$ strongly agreed. This means therefore that inservice training increases confidence among student based on the findings.

From the above Table $7,1.3 \%$ of the respondents disagreed that in-service teacher training

Enhances student academic achievement; $14.7 \%$ were neutral, $63.9 \%$ agreed on the issue, and $20.2 \%$ strongly agreed. This means therefore that in-service teacher training enhances student academic achievement.

From the above Table $8,45.8 \%$ of the respondents were neutral that in-service training of teachers lead to high performance among teachers, $46.6 \%$ agreed while $7.6 \%$ strongly agreed. The implication is that in-service training of teachers lead to high performance among teachers. 
Table 3. In-service teacher training advances training in class for better results

\begin{tabular}{lcccc}
\hline & Frequency & Percent & Valid Percent & Cumulative Percent \\
\hline Disagree & 9 & 3.8 & 3.8 & 3.8 \\
Neutral & 42 & 17.6 & 17.6 & 21.4 \\
Agree & 116 & 48.7 & 48.7 & 70.2 \\
Strongly agree & 71 & 29.8 & 29.8 & 100.0 \\
\hline Total & $\mathbf{2 3 8}$ & $\mathbf{1 0 0 . 0}$ & $\mathbf{1 0 0 . 0}$ & \\
\hline
\end{tabular}

Source: Field data 2021

Table 4. In-service training and teaching skills

\begin{tabular}{|c|c|c|c|}
\hline & & $\begin{array}{l}\text { In-service teacher training } \\
\text { advances training in class for } \\
\text { better results }\end{array}$ & $\begin{array}{l}\text { In-service teacher leads to } \\
\text { creativity and training }\end{array}$ \\
\hline \multirow{3}{*}{$\begin{array}{l}\text { In-service teacher training } \\
\text { advances training in class for } \\
\text { better results }\end{array}$} & Pearson Correlation & 1 & $.232^{* *}$ \\
\hline & Sig. (2-tailed) & & .000 \\
\hline & $\mathrm{N}$ & 238 & 238 \\
\hline \multirow{3}{*}{$\begin{array}{l}\text { In-service teacher leads to } \\
\text { creativity and training }\end{array}$} & Pearson Correlation & $.232^{* *}$ & 1 \\
\hline & Sig. (2-tailed) & .000 & \\
\hline & $\mathrm{N}$ & 238 & 238 \\
\hline
\end{tabular}

**. Correlation is significant at the 0.01 level (2-tailed).

Table 5. In-service teacher leads to creativity and training

\begin{tabular}{lcccc}
\hline & Frequency & Percent & Valid Percent & Cumulative Percent \\
\hline Disagree & 16 & 6.7 & 6.7 & 6.7 \\
\hline Neutral & 70 & 29.4 & 29.4 & 36.1 \\
Agree & 106 & 44.5 & 44.5 & 80.7 \\
Strongly agree & 46 & 19.3 & 19.3 & 100.0 \\
\hline Total & $\mathbf{2 3 8}$ & $\mathbf{1 0 0 . 0}$ & $\mathbf{1 0 0 . 0}$ & \\
\hline
\end{tabular}

Source: Field data 2021

Table 6.In-service training increases confidence among students

\begin{tabular}{lccc}
\hline Frequency & Percent & Valid percent & Cumulative Percent \\
\hline Strongly agree & 2 & 8 & 8 \\
Disagree & 2 & 8 & 8 \\
Neutral & 62 & 26.1 & 26.1 \\
Agree & 125 & 52.5 & 52.5 \\
\hline Strongly agree & 47 & 19.7 & 19.7 \\
\hline
\end{tabular}

Source: Field data 2021

The findings in Table 9 above show that in-service training and are significantly related $(r=328$ at $p=.00<0.01)$ hence rejecting the null hypothesis. In-service teacher training contributes positively in academic performance. The in-service teacher training enables the teachers to be more systematic and logical in their teaching style.

According to the Table 10, $4 \%$ of the respondents strongly disagreed with the statement that in-service teacher training promote knowledge on choice and use of effective teaching methods, $4 \%$ disagreed, $30.7 \%$ were neutral $\%, 48.3 \%$ agreed, while $20.2 \%$ strongly agreed. The implication is that in-service teacher training promote knowledge on choice and use of effective teaching methods based on the findings.

From the above Table 11, 4\% of the respondents strongly disagreed with the statement that in-service teacher training promote knowledge on choice and use of effective teaching methods, $4 \%$ disagreed, $30.7 \%$ were neutral $\%, 48.3 \%$ agreed, while $20.2 \%$ strongly agreed. The implication is that in-service teacher training promote knowledge on choice and use of effective teaching methods based on the findings.

From the above Table 12, 4\% of the respondents strongly disagreed with the statement that in-service teacher training 
Table 7. In-service teacher training enhances student academic achievement

\begin{tabular}{lccc}
\hline Frequency & Percent & Valid percent & Cumulative Percent \\
\hline Disagree & 3 & 1.3 & 1.3 \\
Neutral & 35 & 14.7 & 16.0 \\
Agree & 152 & 63.9 & 79.8 \\
Strongly agree & 48 & 20.2 & 100.0 \\
\hline Total & $\mathbf{2 3 8}$ & $\mathbf{1 0 0 . 0}$ & \\
\hline
\end{tabular}

Source: Field data 2021

Table 8. In-service training of teachers lead to high academic performance among teachers

\begin{tabular}{lcccc}
\hline & Frequency & Percent & Valid Percent & Cumulative Percent \\
\hline Neutral & 109 & 45.8 & 45.8 & 45.8 \\
Agree & 111 & 46.6 & 46.6 & 92.4 \\
Strongly agree & 18 & 7.6 & 7.6 & 100.0 \\
\hline Total & $\mathbf{2 3 8}$ & $\mathbf{1 0 0 . 0}$ & $\mathbf{1 0 0 . 0}$ & \\
\hline
\end{tabular}

Primary data, 2021

Table 9. Correlation between in-service training and academic performance

\begin{tabular}{lccc}
\hline & In-service & $\begin{array}{c}\text { academic } \\
\text { training }\end{array}$ & $\begin{array}{c}\text { achievement } \\
\text { aching }\end{array}$ \\
\hline In-service training & Pearson Correlation & 1 & $.328^{* *}$ \\
& Sig. (2-tailed) & & .000 \\
& $\mathrm{~N}$ & 238 & 238 \\
\hline Academic achievement & Pearson Correlation & $.328^{* *}$ & 1 \\
& Sig. (2-tailed) & .000 & \\
& $\mathrm{~N}$ & 238 & 238 \\
\hline
\end{tabular}

**. Correlation is significant at the 0.01 level (2-tailed).

Table10. In-service teacher training promote knowledge on choice and use of effective teaching methods

\begin{tabular}{lcccc}
\hline & Frequency & Percent & Valid percent & Cumulative percent \\
\hline Strongly disagree & 1 & 4 & 4 & 4 \\
Disagree & 1 & 4 & 4 & 4 \\
Neutral & 73 & 30.7 & 30.7 & 31.5 \\
Agree & 115 & 48.3 & 48.3 & 79.8 \\
Strongly agree & 48 & 20.2 & 20.2 & 100.0 \\
\hline Total & $\mathbf{2 3 8}$ & $\mathbf{1 0 0 . 0}$ & $\mathbf{1 0 0 . 0}$ & \\
\hline
\end{tabular}

Primary data, 2021

Table11. In-service teacher training promote knowledge on choice and use of effective teaching methods

\begin{tabular}{lcccc}
\hline & Frequency & Percent & Valid percent & Cumulative Percent \\
\hline Strongly disagree & 1 & .4 & .4 & .4 \\
Disagree & 1 & .4 & .4 & .8 \\
Neutral & 73 & 30.7 & 30.7 & 31.5 \\
Agree & 115 & 48.3 & 48.3 & 79.8 \\
Strongly agree & 48 & 20.2 & 20.2 & 100.0 \\
\hline Total & $\mathbf{2 3 8}$ & $\mathbf{1 0 0 . 0}$ & $\mathbf{1 0 0 . 0}$ & \\
\hline
\end{tabular}

Primary data, 2021

improve teacher quality and ultimately enhance student performance, $8 \%$ disagreed, $6.3 \%$ were neutral, majority $81.1 \%$ agreed, while $11.3 \%$ strongly agreed. The implication is that inservice training improves on the quality as revealed by the 
Table12. In-service teacher training improve teacher quality and ultimately enhance student performance

\begin{tabular}{lcccc}
\hline & Frequency & Percent & Valid Percent & Cumulative Percent \\
\hline Strongly disagree & 1 & .4 & .4 & .4 \\
\hline Disagree & 2 & .8 & .8 & 1.3 \\
Neutral & 15 & 6.3 & 6.3 & 7.6 \\
\hline Agree & 193 & 81.1 & 81.1 & 88.7 \\
\hline Strongly agree & 27 & 11.3 & 11.3 & 100.0 \\
\hline Total & $\mathbf{2 3 8}$ & $\mathbf{1 0 0 . 0}$ & $\mathbf{1 0 0 . 0}$ & \\
\hline
\end{tabular}

Source: Field data 2021

Table13. Refresher courses have improved my performance

\begin{tabular}{lcccc}
\hline & Frequency & Percent & Valid Percent & Cumulative Percent \\
\hline Neutral & 88 & 37.0 & 37.0 & 37.0 \\
Agree & 118 & 49.6 & 49.6 & 86.6 \\
Strongly agree & 32 & 13.4 & 13.4 & 100.0 \\
Total & $\mathbf{2 3 8}$ & $\mathbf{1 0 0 . 0}$ & $\mathbf{1 0 0 . 0}$ & \\
\hline
\end{tabular}

Source: Field data 2021

Table14. Workshops and seminars improves teachers performance

\begin{tabular}{lcccc}
\hline & Frequency & Percent & Valid Percent & Cumulative Percent \\
\hline Disagree & 18 & 7.6 & 7.6 & 7.6 \\
Neutral & 62 & 26.1 & 26.1 & 33.6 \\
Agree & 139 & 58.4 & 58.4 & 92.0 \\
Strongly agree & 19 & 8.0 & 8.0 & 100.0 \\
\hline Total & $\mathbf{2 3 8}$ & $\mathbf{1 0 0 . 0}$ & $\mathbf{1 0 0 . 0}$ & \\
\hline
\end{tabular}

Source: Field data 2021

findings.

From the above Table $13,37.0 \%$ of the respondents were neutral with the statement that refresher courses have improved my performance, $49.6 \%$ agreed and 13.4 strongly agreed. This implies that refresher courses have improved students performance.

From the above Table $14,7.6 \%$ of the respondents disagreed with the statement, $26.1 \%$ were neutral on the issue, $58.4 \%$ agreed while $8.0 \%$ strongly agreed. This implies that workshops and seminars improves teachers performance.

From the above Table 15, $8 \%$ of the respondents strongly disagreed with the statement that In-service teacher training helps teachers to discover their talent, $8.8 \%$ disagreed, $34.9 \%$ were neutral, 31.9 agreed while $23.5 \%$ strongly agreed. The study findings showed that $5.0 \%$ of the respondents disagreed that inservice teacher training improves teacher-student learning process, $34.9 \%$ were neutral, $50.0 \%$ agreed, and $10.1 \%$ strongly agreed. The findings further revealed that well trained teachers deliver the subject content professionally and effectively in students, $13.0 \%$ disagreed, $18.9 \%$ were neutral, $49.6 \%$ agreed, $18.5 \%$ strongly agreed. The study further revealed that $10.5 \%$ noted that in-service teacher training improves on teaching skills for better results among teachers in school 19.3\% were neutral, $52.9 \%$ agreed and $17.2 \%$ strongly agreed. The study further revealed that $4 \%$ noted that In-service teacher training improves on teachers' knowledge that they impart on teachers behaviors in school, 8\% disagreed, $22.3 \%$ were neutral, $45.8 \%$ agreed and $30.7 \%$ strongly agreed. The findings also showed that the biggest percentage of respondents agreed with 44.1\%, 37.8\% were neutral and $8.4 \%$ strongly agreed. The study further revealed that $11.3 \%$ noted that high performing schools take more interest in staff training program to ensure that teachers acquire new knowledge and skills, $58.8 \%$ were neutral, $18.1 \%$ agreed, $11.8 \%$ strongly agreed as revealed by the findings in the table above

In addition to analysis of in-service training and teacher's performance, the study considered analyzing relationship between training and teachers performance in secondary schools as evaluated by students. Tables 16 show test results are shown above.

The findings in Table 17 above show that teachers training and teachers performance are significantly related $(r=077$ at $\mathrm{p}=.00<0.01$ ) hence rejecting the null hypothesis. This implies that in-service training leads to an increase in teacher's performance and vice versa. This implies that when teachers participate in training, it can improve teacher quality and ultimately enhance their performance. Therefore sustained and intensive training is more likely to have an influence on enhanced teacher knowledge and skills and consequently student achievement than short training activities. It is also worth noting that teachers who are well prepared and trained are more effective teachers in the classroom and therefore have the greatest influence on the student achievement

According to Table 18, 2.5\% of the respondents strongly disagreed with the statement that In-service teacher training motivates teachers for better results, $21.0 \%$ disagreed, $37.8 \%$ were neutral, $37.4 \%$ agreed and $4 \%$ strongly agreed. The findings further revealed that in-service teacher training helps in time management among teachers, $15.5 \%$ disagreed, $36.1 \%$ were 
Table 15. Response on how in-service training has contributed on teacher's performance in Kisoro District

\begin{tabular}{|c|c|c|}
\hline Variable & Frequency(238) & Percentage (\%) \\
\hline \multicolumn{3}{|c|}{ in-service training helps teachers } \\
\hline Strongly disagree & 2 & 8.0 \\
\hline Disagree & 21 & 8.8 \\
\hline Neutral & 83 & 34.9 \\
\hline Agree & 76 & 31.9 \\
\hline Strongly agree & 56 & 23.5 \\
\hline Total & 238 & 100.0 \\
\hline \multicolumn{3}{|c|}{ In-service training improves teacher-student learning } \\
\hline Disagree & 12 & 5.0 \\
\hline Neutral & 83 & 34.9 \\
\hline Agree & 119 & 50.0 \\
\hline Strongly agree & 24 & 10.1 \\
\hline Total & 238 & 100 \\
\hline \multicolumn{3}{|c|}{ Well trained teachers deliver subject content } \\
\hline Disagree & 31 & 13.0 \\
\hline Neutral & 45 & 18.9 \\
\hline Agree & 118 & 49.6 \\
\hline Strongly agree & 44 & 18.5 \\
\hline \multicolumn{3}{|c|}{ In-service training improves teaching } \\
\hline Disagree & 25 & 10.5 \\
\hline Neutral & 46 & 47.5 \\
\hline Agree & 126 & 52.9 \\
\hline Strongly agree & 41 & 17.2 \\
\hline \multicolumn{3}{|c|}{$\begin{array}{l}\text { In-service teacher training improves teacher's } \\
\text { knowledge }\end{array}$} \\
\hline Strongly disagree & 1 & 4.0 \\
\hline Disagree & 2 & 8.0 \\
\hline Neutral & 53 & 22.3 \\
\hline Agree & 109 & 45.8 \\
\hline Strongly agree & 73 & 30.7 \\
\hline Total & 238 & 100.0 \\
\hline \multicolumn{3}{|c|}{$\begin{array}{l}\text { Motivated and competent teachers are more effective, } \\
\text { productive and enegetic }\end{array}$} \\
\hline Disagree & 1 & 4 \\
\hline Neutral & 107 & 45.0 \\
\hline Agree & 80 & 33.6 \\
\hline Strongly agree & 50 & 21.0 \\
\hline Total & 238 & 100.0 \\
\hline \multicolumn{3}{|c|}{$\begin{array}{l}\text { In-service teacher training helps teachers to enhance } \\
\text { their teaching }\end{array}$} \\
\hline Disagree & 23 & 9.7 \\
\hline Neutral & 90 & 37.8 \\
\hline Agree & 105 & 44.1 \\
\hline Strongly agree & 20 & 8.4 \\
\hline Total & 238 & 100.0 \\
\hline \multicolumn{3}{|c|}{$\begin{array}{l}\text { High performing schools take more interest in staff } \\
\text { training program to ensure that teachers acquire } \\
\text { knowledge and skills among teachers }\end{array}$} \\
\hline Disagree & 27 & 11.3 \\
\hline Neutral & 140 & 58.8 \\
\hline Agree & 43 & 18.1 \\
\hline Strongly agree & 28 & 11.8 \\
\hline Total & 238 & 100.0 \\
\hline
\end{tabular}

Source: Field data 2021

neutral, $42.0 \%$ agreed and $63 \%$ strongly agreed. The study further revealed that $25.6 \%$ strongly disagreed that teacher training enhance content delivery in school, $34.0 \%$ were neutral, $31.9 \%$ agreed and $8.4 \%$ strongly agreed. The study further revealed that $1.5 \%$ of the respondents noted that trained teachers acquire more knowledge which can help them to deliver content while in class, 
Table 16. One-Sample Statistics between in-service training and teacher's performance

\begin{tabular}{lcccc}
\hline & $\mathbf{N}$ & Mean & Std. Deviation & Std. Error Mean \\
\hline In-service Training & 238 & 1.4412 & .36647 & .87012 \\
\hline Teachers' Performance & 238 & 1.4765 & .25676 & .96690 \\
\hline
\end{tabular}

Table 17. Relationship between in-service training and teacher's performance

\begin{tabular}{lccc}
\hline & & In-service training & Teachers Performance \\
\hline & Pearson Correlation & 1 & 077 \\
In-service training & Sig. (2-tailed) & & 497 \\
& $\mathrm{~N}$ & 138 & 138 \\
& Pearson Correlation & 077 & 1 \\
Teachers Performance & Sig. (2-tailed) & 497 & 138 \\
\hline
\end{tabular}

**. Correlation is significant at the 0.01 level (2-tailed).

$26.5 \%$ were neutral, $46.6 \%$ agreed and $11.3 \%$ strongly agreed. The findings also showed that the biggest percentage of respondents $54.2 \%$ agreed that in service teacher training provides opportunities for increasing the number of trained and qualified teachers in secondary schools, $11.8 \%$ disagreed, $16 \%$ were neutral and $18.1 \%$ strongly agreed as revealed by the findings in the table above.

\section{DISCUSSION OF RESULTS}

The study established that in-service teacher training improves on teaching skills for better results. Pynes (2004) argues in the same line, when he stresses that in-service training helps teachers to expand their current knowledge of a subject/phase/matter, develop new knowledge and engage with colleagues at their current school and others schools. It is assumed that a welltrained teacher will deliver the subject content professionally and effectively. This should be a reality by all manners of fairness though studies show that apart from the acquired skills by these teachers, factors such as environmental, economic and sociocultural, among others, also play a major part in determining the students' performance in examinations (Jackson and Davis, 2000). For better grades to be attained in schools there is need for proper linkages amongst these factors. A trained teacher usually analyses these factors and incorporates them in the teaching practices.

Further, in-service teacher training leads to improvements in time management by the teachers. Darling- Hammond (2017) established that more productive teacher and professional training programs make a difference to the teachers' abilities to utilize their available time in the teaching and learning process. However, a separate study done by Ngala and Odebero (2010) in primary schools majorly in Rift Valley province indicated that some teachers have tight work schedule thus lack time to prepare for their teaching duties. This also interferes with their participation in the training programs.

Further, the study established that in-service teacher training improves on teaching skills for better results. Darling-Hammond and Gardner, 2017) argues in the same line, when he stresses that in-service training helps teachers to expand their current knowledge of a subject/phase/matter, develop new knowledge and engage with colleagues at their current school and others schools. It is assumed that a well-trained teacher will deliver the subject content professionally and effectively. This should be a reality by all manners of fairness though studies show that apart from the acquired skills by these teachers, factors such as environmental, economic and socio-cultural, among others, also play a major part in determining the students' performance (Jackson and Davis, 2000). For better grades to be attained in schools there is need for proper linkages amongst these factors (Pauwe, 2004). A trained teacher usually analyses these factors and incorporates them in the teaching practices.

\section{Recommendations}

In service training should not just stop at university or college levels. The short training courses like workshops, seminars and in -service training are very necessary and should be encouraged. As such, we highly recommend that there should be serious initiatives to embark on the route of the training and professionalization of teachers and teacher education along competence lines. Those trainings and professional development programs should focus on core content knowledge, teaching skills, teaching strategies, and assessment strategies, among others. There should be an alignment of educational programs content with what teachers teach, need and experience in their classrooms.

Selection and organization of content should be in line with the context in terms of environment and needs as per a given locality. Relevant selection of what to teach or learn will be productive in improving performance by teachers in their line of duty and that of the students, the target of the learning and teaching process. Teaching materials which are current and relevant should be made available to enhance training. Facilitators and administrators should have reliable records of participants who attend and the programme they attend. Should also have records of who are due to go and those who are yet to attend training to avoid a possible missout to attend by some teachers. Newly employed teachers should be included in the in-service training. Facilitators should be more than two. Teaching and learning materials should be made available before training commences and these programs should focus on core content knowledge, teaching skills, teaching strategies, and assessment strategies, among others. There should be an alignment of educational programs content with what teachers teach, need and experience in their classrooms.

At the planning stage, financial matters should be best attended to by having a budget good enough to meet training needs by teachers. If enough funds are allocated, many stake holders will 
Table18. Teachers Views on In-Service Teacher Training Programs District

\begin{tabular}{|c|c|c|}
\hline Variable & Frequency(238) & Percentage (\%) \\
\hline \multicolumn{3}{|c|}{ in-Service teacher training motivates } \\
\hline Strongly disagree & 6 & 2.5 \\
\hline Disagree & 50 & 21.0 \\
\hline Neutral & 92 & 38.7 \\
\hline Agree & 89 & 37.4 \\
\hline Strongly agree & 1 & 4.0 \\
\hline Total & 238 & 100.0 \\
\hline \multicolumn{3}{|c|}{ In-service teacher training helps in time management } \\
\hline Disagree & 61 & 15.5 \\
\hline Neutral & 81 & 34.0 \\
\hline Agree & 100 & 42 \\
\hline Strongly agree & 15 & 6.5 \\
\hline Total & 238 & 100 \\
\hline \multicolumn{3}{|c|}{ Teacher training enhance content delivery } \\
\hline Disagree & 61 & 25.6 \\
\hline Neutral & 81 & 34.0 \\
\hline Agree & 76 & 31.9 \\
\hline Strongly agree & 20 & 8.4 \\
\hline \multicolumn{3}{|c|}{ Trained teachers acquire more skill \& knowledge } \\
\hline Disagree & 61 & 25.6 \\
\hline Neutral & 81 & 34.0 \\
\hline Agree & 76 & 31. \\
\hline Strongly agree & 20 & 17.2 \\
\hline \multicolumn{3}{|c|}{$\begin{array}{l}\text { In-service training helps teachers to be more disciplined and committed to } \\
\text { their work }\end{array}$} \\
\hline Disagree & 47 & 19.7 \\
\hline Neutral & 78 & 32.8 \\
\hline Agree & 95 & 39.9 \\
\hline Strongly agree & 18 & 7.6 \\
\hline Total & 238 & 100.0 \\
\hline \multicolumn{3}{|c|}{ In-service teacher training enhances high levels of creativity and innovation } \\
\hline Strongly disagree & 2 & 8 \\
\hline Neutral & 77 & 32.4 \\
\hline Agree & 132 & 55.5 \\
\hline Strongly agree & 27 & 11.3 \\
\hline Total & 238 & 100.0 \\
\hline \multicolumn{3}{|c|}{ In-service training improves teachers interpersonal skills } \\
\hline Disagree & 1 & 4 \\
\hline Neutral & 28 & 11.8 \\
\hline Agree & 96 & 40.3 \\
\hline Strongly agree & 113 & 47.5 \\
\hline Total & 238 & 100.0 \\
\hline \multicolumn{3}{|c|}{$\begin{array}{l}\text { Trained teachers acquire more knowledge and skills which can help to deliver } \\
\text { more content while in class }\end{array}$} \\
\hline Disagree & 22 & 9.2 \\
\hline Neutral & 80 & 33.6 \\
\hline Agree & 108 & 45.4 \\
\hline Strongly agree & 28 & 11.8 \\
\hline Total & 238 & 100.0 \\
\hline \multicolumn{3}{|c|}{$\begin{array}{l}\text { In-Service teacher training provides opportunities for increasing the number } \\
\text { of trained and qualified teachers in secondary schools }\end{array}$} \\
\hline Disagree & 28 & 11.8 \\
\hline Neutral & 38 & 16.0 \\
\hline Agree & 129 & 54.2 \\
\hline Strongly agree & 43 & 18.1 \\
\hline Total & 238 & 100.0 \\
\hline
\end{tabular}

participate hence the impact of in-service teacher training will be extended. Trainees should be facilitated according to the circulars pertaining to public services. The training should be conducted at council or regional levels. 
Teachers should frequently be afforded study leaves or time off to do training. During this period, the school can hire part-time teachers so that normal learning is not disrupted. It's important to appreciate that continual professional development gives teacher's time to learn and implement new strategies. Topics should not be many compared to the allocated time. In-service teacher training should at least be conducted twice a year rather than what seems to be a traditional once a year. Training should be conducted at a level to which many teachers can access, for example at the district level.

\section{Conclusions}

According to the findings by this study, in-service training, faces a number of challenges which if not attended may retard its positive contribution to the improvement of teaching and learning process in secondary schools. Some of the revealed challenges include; limited budget which limit the number of participants as it could have otherwise been. Selection of teachers to attend in-service training programs. Other challenges included; limited time allocated to run in-service programs compared to the content to be covered, Interviewed teachers also said revealed that sometimes facilitators do not show masterly of the subject matter/content.

It was established through the current study that in-service teacher training contributes positively in academic performance. For the case of public secondary schools in Kisoro district, there was a noted good students academic performance in their UNEB exams implying that, improve teaching and learning process as by in-service training affects students academic performance positively.

Findings show that, proper inservice training does improve the teachers performance. That means when in-service teacher training programmes are introduced through best strategies like, doing research to determine the needs, selecting teachers/participants as per best established criteria, being as inclusive as possible by involving many participants, using up to date and relevant teaching and learning materials, establishing appropriate intervals between one cohorts and using competent trainers, among others, bring positive results. A poorly run inservice teacher training affects teaching and learning process negatively hence poor students performance.

\section{Conflict of interests}

The authors declare that they have no conflicting interests.

\section{REFERENCES}

Adile AK, Muhterem D (2012), Teachers' views about effective use of technology in classrooms; Turkish online J. qualitative inquiry 3(2):30-41.

Ahmadi S, Keshavarzi A (2013). A survey of in-service training programs effectiveness in teaching skill development from the view-point of students, teachers and principals of guidance schools in Shiraz. Procediasocial and behavioral sciences, 83:920-925.

Akhter SH, Ali Shah S, W Nasee ud Din M (2011). A Critical Analysis of the existing status of the IN-Service Training of teachers at Secondary level in Khyber Pakhtunkhwa. Int. J. Acad. Res. 3(6):417-420.
Castillo R, Brackett MA (2013). Enhancing teacher effectiveness in Spain: A pilot study of the RULER approach to social and emotional learning.

Cimer S0, Cakir I, Cimer A (2010). Teachers Views on the effectiveness of in-service course on the new curriculum in Turkey. European J. Teacher Educ., 33 (1):31-41.

Darling-Hammond L, Hyler ME, Gardner M (2017). Effective Teacher Professional Development.

Duyga S, Muhterem D (2012), Teachers' views about effective use of technology in classrooms; Turkish online J. Qualitative inquiry 3(2):30-41.

Ferguson R, Ladd H (2011). How And Why Money Matters: An Analysis of Alabama Schools. Holding School Accountable: Performance Based Reform in Education Washington, D.C.: Brookings Institute.

Guskey T, Clifford R (2013). Evaluating professional development. Thousand Oaks CA: Corwin Press.

Hill CH, Rowan B, Ball DL (2015). Effects of teachers' mathematical knowledge for teaching on student. American Educational Research J. .826416

Jackson A, Davis G (2000). Turning Points 2000: Educating Adolescents in the 21st Century. New York: Teachers College Press

Kazmi SF, Pervez T, Mumtaz S (2011). In-Service Teacher Training in Asian Nation Faculties and Total Quality Management, Knowledge Base J. Contemporary Research In Business.

Khan AR, Khandaker S (2016). A Critical Insight into Policy Implementation and Implementation Performance. Public Policy and Administration.15(4):538-548.

Kirkpatrick SA, Locke EA (1996). Direct and indirect effect of three core charismatic leadership components on performance and attitude. J. Appl. Psychol., 81(1):36-51.

Merfat AA (2016). Curriculum development: Teacher Involvement in curriculum development. Public Policy and Administration 3(1):106-107

Morgan E (2010). Benefits of Professional Development. Austin: ACT Inc.

Ngala F, Oriosky N, Odebero S (2010). Teachers' perceptions of staff development as it relates to teachers' effectiveness: A study of rural primary schools in Kenya. Education Research and Reviews .

Okiror JJ, Winterbottom M (2017). Towards in-service training needs of secondary school agriculture teachers in a paradigm shift to outcome-based education in Uganda. J. Agric. Educ. and Extension, 23(5):415-426.

Osamwonyi EF (2016), In-service education of teachers: Overview, problems and the way forward. J. Education and Practice, 2 (2):81-87

Pynes JE (2004). Human Resource Management for public and Non-Profit organization , 2nd ed, Jossey-Base,

Robson (2002). Learning the Craft of Qualitative. Research Interviewing. (2nd Ed.).Thousand Okas CA: Sage

Wenglinsky H (2010). How Teaching Matters: Bridging the Classroom back into Discussion of Teacher Quality Education Testing Service. Chicago Consortium Press.

Wetungu M (2012). Human resource practices, teamwork and perceived teachers' performance in secondary 
schools in Kampala city council and Wakiso district; Unpublished MHR Dissertation HRM Department; Makerere University 